\title{
Causal Relationship among Education Expenditure, Health Expenditure and GDP: A Case Study for Bangladesh
}

\author{
Md. Mostafizur Rahman (Corresponding author) \\ Department of Statistics, Statistics and Mathematics School \\ Yunnan University of Finance and Economics, Kunming-650221, P.R. China \\ E-mail: mostafiz_bd21@yahoo.com
}

Received: November 10, $2010 \quad$ Accepted: December 21, $2010 \quad$ doi:10.5539/ijef.v3n3p149

This research was supported by National Natural Science Foundation of China (YCT1017)

\begin{abstract}
This paper investigated the causal relationship among health expenditure, education expenditure and GDP for Bangladesh. First we present the extension form of the augmented Solow Growth model by including education expenditure and health expenditure as education and health capital. In our empirical study we used time series data for the period 1990 to 2009. From the ECM methodology we found that an including of health and education expenditure as an investment in health and education capital improve the significance of the coefficient of human and physical capital in the growth model for Bangladesh. Secondly, we find out the causal relationship among these variables by Var Granger Causality test. From the empirical study we found the existence of bidirectional causality from education expenditure to GDP and also from education expenditure to health expenditure and only unidirectional causality is obtained from health expenditure to GDP. This paper will provide a significant policy guideline to the policy maker.
\end{abstract}

Keywords: Education capital, Extended Solow growth model, VAR Granger Causality test, GDP, Bangladesh

\section{Introduction}

Education has been recognized as an investment not only for creating human capital, but also for inducing social change and promoting overall development. The vision of education as a proactive intervention for desired change got grudging recognition over time in development thinking; although, the case for emphasizing labor productivity for creating surplus for investment has been advocated by Adam Smith and others since the 18th century.

According to the both theoretical and empirical growth literature, technological change is the main source of growth and differences in the rate of technological change are the principal cause of income differences across countries (Klenow and Rodriguez-Clare (1997), Hall and Jones (1999), Easterly and Levine (2001)). For technological change to occur countries need to engage in innovation or imitation activities that use primarily human capital as an input (Nelson and Phelps (1966), Romer (1990a), Romer (1990b), Abramovitz (1986)). Since formal education is an important source of human capital, the study of the relationship between education, technological change and growth can provide important insights on the causes of income differences across countries. Another important issue in this perspective has been highlighted by Siddiqui, Afridi, and Haq, (1995) that improvement in the health status of the population of human capital formation. Improved health status of a nation creates an outward shift in the labor supply curve and increases productivity of labor with an increase in the productivity of investment in other forms of human capital.

After the work of Solow (1956), many authors significantly developed the theoretical and empirical literature on endogenous growth models. This initial work analyzed economic growth by assuming a neoclassical production function with decreasing returns to capital in which rates of saving and population growth were considered exogenous. The model was augmented by Mankiw, Romer and Weil (1992) with the including of human capital known as the MRW model. Later Barro (1997); Gemmell (1996) found human capital as a significant factor in determining growth. Similarly, Miller and Upadhyay (2000) examined a significant impact of interaction between human capital and openness as a measure for the country's ability to absorb technological advances; this has a significant effect on total factor productivity. Aurangzeb (2003) examined the temporal interdependence between gross domestic product and health expenditure per capita for Pakistan in an augmented Solow growth model with only including health expenditure as a health capital and found a significant and positive relationship between GDP and Health Expenditure, both in the long-run and short-run. Chang and Ying (2005) applied economic growth theory 
to explain the long-term increasing nature of healthcare expenditure in a growing economy. They considered health consumption as an investment in human capital because it improves labor's working ability by promoting worker reliability, energy and attention and finally they applied this model for 15 OECD countries for their empirical analysis. Grigoriou and Graziosi (2005) analyzed the effects of education and health expenditures on child labor for some developing countries and found that each type of public spending influence on the individual trade-off through a particular way: the education spending increases the return of education, while the health spending reduces the risk of children death. Himissa et al (2009) explored the inter-relationship between military expenditure, education expenditure and health expenditure for Malaysia, Indonesia, Singapore, Philippines, Bangladesh, Nepal, Sri Lanka and South Korea and found that except for the case of Malaysia and Sri Lanka, whereby no meaningful interrelationship was detected between these three variables, the results for the rest of the countries are mixed, with differing granger causality being detected among these variables. The mixed results obtained in this study is an indicator of differing policy being implemented and will result in varying implication. Generally the error correction term is significant. Implying there is long-run relationship between defense spending, education and health expenditure. Nancy and Paul (2001) examined the granger causality between health care expenditure and economic growth for 20 OECD countries. From these earlier studies we found that most of researchers used cross country panel data analysis. Moreover, none of them included education expenditure as an education capital with Solow Growth Model. So, the aim of this paper is twofold. First we present the extension form of an Augmented Solow Growth model in a Cobb-Douglas functional form by including health and education expenditure as health and education capital and check either this inclusion variable can improve the significance of the coefficient of human and physical capital or not in case of Bangladesh. Secondly we used Granger Causality/Block Exogeneity Wald Tests to examine the causal relationship among these variables. The organization of this paper is as follows: The introduction and some previous studies are given in section 1.Section 2 presents the methodology. Section 3 presents the empirical study and finally section 4 presents the conclusions.

\section{Methodology}

We will discuss the stationarity, Cointegration tests and Granger Causality test. We also present the extended form of Solow Growth model by including Education and health capital.

\subsection{Stationarity}

To determine the non-stationary property of these time series variables, the relevant DF and ADF test have been employed. The DF test is based on the following model:

$$
\Delta Z_{t}=\delta+(\rho-1) Z_{t-1}+\lambda T+\varepsilon_{1 t}
$$

The ADF test is a modification over the DF test and lagged values of the dependent variables are added in estimation of equation (1) which is formed as follows:

$$
\Delta Z_{t}=\delta+(\rho-1) Z_{t-1}+\lambda T+\gamma \Delta Z_{t-1}+\varepsilon_{2 t}
$$

Since it is widely believed that both DF and ADF test do not consider the cases of heteroscedasticity and non-normality frequently revealed in a raw data of economic time series variables the PP test for unit root has been used in the empirical analysis. Moreover, it has an advantage over the ADF test when the concerned time series has serial correlation and there is a structural break. Therefore, the PP test provides robust estimates over DF and ADF tests and is based on the following form of equation

$$
\Delta Z_{t}=\phi+(\rho-1) Z_{t-1}+\lambda(t-T / 2)+\psi \Delta Z_{t-i}+\varepsilon_{3 t}
$$

The appropriate critical values of time $t$ statistics for the null hypothesis of non-stationarity are given by Mackinnon(1991). Further an alternative testing procedure, KPSS test has been performed where the concerned time series variables are assumed to be trend stationary under null hypothesis (Patterson, 2002). The KPSS test starts from the basic local level model

$$
Z_{t}=\alpha_{t-1}+\beta+h_{t}+\xi_{t}
$$

The KPSS test statistics is based on the following Lagrangian Multiplier (LM) statistic:

$$
\text { KPSS }=\sum_{t}\left(\sum_{r-1}^{t} \hat{u}_{r}\right)^{2} / T^{2} f_{0}
$$


Where $f$ is an estimator of the residuals spectrum at frequency zero. The appropriate critical values for the LM statistic are given by Kwiatkowski-Phillips-Schmidt-shin. At equation (1), (2) and (3) $\Delta$, represent the first difference and $\varepsilon_{1 t}, \varepsilon_{2 t}, \varepsilon_{3 t}$ are the respective stationary random error term.

\subsection{Cointegration tests}

Many micro economic time series data may contain a unit root that has spurred the development of the theory of non-stationary time series analysis. Engle and Granger (1987) show that if two variables are co-integrated i.e., there is a valid long-run relationship, and then there exists a corresponding short-run relationship. This is popularly known as the Granger's Representation Theorem. Hendry's $(1979,1995)$ general-to-specific approach has been applied in this case where the model (i.e., ECM) is used in the following form:

$$
\begin{aligned}
& \Delta Y(t)=\varphi_{10}+\sum_{j=1}^{m 1} \phi_{11} \Delta K(t)_{t-j}+\sum_{i=1}^{m 2} \phi_{12} \Delta Y(t)_{t-i}+\sum_{k=1}^{m 3} \phi_{13} \Delta H(t)_{t-k}+\sum_{x=1}^{m 4} \phi_{14} \Delta Q(t)_{t-x} \\
& +\sum_{y=1}^{m 5} \phi_{15} \Delta B(t)_{t-y}+\sum_{p=1}^{m 6} \phi_{16} \Delta E(t)_{t-p}-\theta_{1} \varepsilon_{t-1}+e_{1 t} \\
& \Delta B(t)=\varphi_{50}+\sum_{j=1}^{m 1} \phi_{51} \Delta K(t)_{t-j}+\sum_{i=1}^{m 2} \phi_{52} \Delta Y(t)_{t-i}+\sum_{k=1}^{m 3} \phi_{53} \Delta H(t)_{t-k}+\sum_{x=1}^{m 4} \phi_{54} \Delta Q(t)_{t-x} \\
& +\sum_{y=1}^{m 5} \phi_{55} \Delta B(t)_{t-y}+\sum_{p=1}^{m 6} \phi_{56} \Delta E(t)_{t-p}-\theta_{5} \varepsilon_{t-1}+e_{5 t} \\
& \Delta E(t)=\varphi_{60}+\sum_{j=1}^{m 1} \phi_{61} \Delta K(t)_{t-j}+\sum_{i=1}^{m 2} \phi_{62} \Delta Y(t)_{t-i}+\sum_{k=1}^{m 3} \phi_{63} \Delta H(t)_{t-k}+\sum_{x=1}^{m 4} \phi_{64} \Delta Q(t)_{t-x} \\
& +\sum_{y=1}^{m 5} \phi_{65} \Delta B(t)_{t-y}+\sum_{p=1}^{m 6} \phi_{66} \Delta E(t)_{t-p}-\theta_{6} \varepsilon_{t-1}+e_{6 t}
\end{aligned}
$$

where $\Delta$ represent the difference operator, $\theta_{1}, \theta_{5}, \theta_{6}$ are the error correction term, $e_{1 t}, e_{5 t}, e_{6 t}$ are the random disturbance terms, $\mathrm{m} 1, \mathrm{~m} 2, \mathrm{~m} 3, \mathrm{~m} 4, \mathrm{~m} 5, \mathrm{~m} 6$ are the number of lag length determined by the Akaike's information criterion (AIC). According to this approach, two lags of both explanatory and dependent variable and one lag of the residual from the co-integrating regression have been included. Here we present the equation only for the series of GDP, health expenditure and education expenditure.

\subsection{Granger Causality test}

Once we have established the long run relationship among education expenditure, health expenditure and GDP, the next steps is to examine the Granger-Causal relationship among these variables. $\mathrm{X}$ is said to be Granger cause to $\mathrm{Y}$ if and only if the forecast of $Y$ is improved by using the past values of $X$ together with the past values of $Y$, than by not doing so (Granger(1969)). Granger causality distinguishes between unidirectional and bi-directional causality. Unidirectional causality is said to exist from $\mathrm{X}$ to $\mathrm{Y}$ if $\mathrm{X}$ causes $\mathrm{Y}$ but $\mathrm{Y}$ does not causes $\mathrm{X}$. If neither of them causes the other, then the two time series are statistically independent. If each of the variables causes the other, then a mutual feedback is said to exist between the variables. In order to test for Granger causality, we will estimate a VAR model as follows, where all variables are initially considered symmetrically and endogenously.

$$
\begin{aligned}
& {\left[L X_{t}\right]=\alpha+\beta_{1}\left[L X_{t-1}\right]+\beta_{2}\left[L X_{t-2}\right]+\ldots+\beta_{n}\left[L X_{t-n}\right]+\left[U_{t}\right]} \\
& X=\left[\begin{array}{llllll}
Y(t) & K(t) & H(t) & Q(t) & B(t) & E(t)
\end{array}\right]^{\prime}
\end{aligned}
$$

Where $t$ is the time subscript, $n$ is the number of lags for the VAR, $\alpha$ is the vector of constant and $\beta_{1}, \beta_{2} \ldots \beta_{n}$ are all parameter matrices and the variables have their usual meaning. 


\subsection{Extended Solow Growth Model}

Solow's model takes the rates of saving, population growth, and technological progress as exogenous variable. There are two inputs; capital and labor which are paid their marginal products. We assume a Cobb-Douglass production function, so production at time $t$ is given by

$$
Y(t)=K(t)^{\alpha} A(t) L(t)^{1-\alpha}, \quad 0<\alpha<1
$$

here $Y(t)$ is real income, $K(t)$ is physical capital, $L(t)$ is labor and $A(t)$ is the level of technology parameter which can be defined as

$$
\log A(t)=\prod Z(t)
$$

at equation (11), $\prod$ represent the parameter vector and $Z(t)$ represent a vector of variables determining total productivity. The vector $Z(t)$ contains the log level of the degree of openness of the economy $Q(t)$. For simplification labor is assumed to grow at rates $a$ is defined as

$$
L(t)=L(0) e^{a t}
$$

Assuming $k(t)=(K(t) / L(t))$ and $y(t)=(Y(t) / L(t))$ as the stock of capital and the level of output per unit of labor respectively, the evolution of capital is governed by

$$
\theta(t)^{k} y(t)-(a+\gamma) k(t)=\theta(t)^{k} k(t)^{\alpha}-(a+\gamma) k(t)
$$

Where $\theta(t)^{k}$ represent the fraction of output invested in physical capital in period $t$, and $\gamma$ is the rate of depreciation. The stock of capital $K(t)$ converges to the steady state value of capital $k(t)^{*}$ is defined as

$$
k(t)^{*}=\left(\theta(t)^{k} /(n+\lambda+\gamma)\right)^{1 /(1-\alpha)}
$$

Putting the value of (14) in (10) and taking log on both sides, the steady state income per capita can be written as

$$
\log (y(t))=\beta_{0}+\frac{\alpha}{1-\alpha} \log \theta(t)^{k}-\frac{\alpha}{1-\alpha} \log (n+\lambda+\gamma)+\varepsilon(t)
$$

This is the simplified form of the Solow model, here $\beta_{0}$ is the intercept and $\varepsilon(t)$ is the random disturbance term. This model has been used as the basic model in empirical specifications (see Barro and Sala-i-Martin (1992)). Later Barro and Lee (1993), Benhabib and Siegel (1994) included human capital as another input of production function. Augmentation of human capital in the growth model proved to be useful concerning the prediction power and the size of $\alpha$, exclusion of human capital creates a specification biased. The production function in equation (10) can be written as:

$$
Y(t)=K(t)^{\alpha} H(t)^{\beta} A(t) L(t)^{1-\alpha-\beta} \quad \alpha+\beta<1
$$

Where $H$ is the stock of human capital which is proxies by average level of education. Then the stock of human capital growth is determined by

$$
\theta(t)^{h} y(t)-(a+\gamma) h(t)=\theta(t)^{h} h(t)^{\beta}-(a+\gamma) h(t)
$$

Where $\theta(t)^{h}$ represent the fraction of output invested in human capital in period $t$ and $h(t)=(H(t) / L(t))$ is the human capital per unit of labor. So equation (15) can written as

$$
\log (y(t))=\beta_{0}+\frac{\alpha}{1-\alpha-\beta} \log \theta(t)^{k}+\frac{\beta}{1-\alpha-\beta} \log \theta(t)^{h}-\frac{\alpha+\beta}{1-\alpha-\beta} \log (n+\lambda+\gamma)+\varepsilon(t)
$$

Now the Solow model can be augmented to investments in health. Then the evolution of health expenditure is determined by

$$
\theta(t)^{b} y(t)-(a+\gamma) b(t)=\theta(t)^{b} b(t)^{\delta}-(a+\gamma) b(t)
$$


Where $\theta(t)^{b}$ is a fraction of output invested in health capital in the period time $t$ and $b(t)=(B(t) / L(t))$ is human capital per unit labor. We found from (18)

$$
\begin{aligned}
& \log (y(t))=\beta_{0}+\frac{\alpha}{1-\alpha-\beta-\delta} \log \theta(t)^{k}+\frac{\beta}{1-\alpha-\beta-\delta} \log \theta(t)^{h}+\frac{\delta}{1-\alpha-\beta-\delta} \log \theta(t)^{b} \\
& -\frac{\alpha+\beta+\delta}{1-\alpha-\beta-\delta} \log (n+\lambda+\gamma)+\varepsilon(t)
\end{aligned}
$$

The form of equation (20) has been used by Aurangzeb (2003) only by including health expenditure with Solow Growth model. Similarly if we consider education expenditure as an another investments in education capital then the Solow model can be extended as the following way

$$
\theta(t)^{e} y(t)-(a+\gamma) e(t)=\theta(t)^{e} e(t)^{\xi}-(a+\gamma) e(t)
$$

Where $\theta(t)^{e}$ is a fraction of output invested in education capital at time period $t$ and $e(t)=(E(t) / L(t))$ is human capital per unit labor. Now the final extended Solow model with including health and education capital can be written as

$$
\begin{aligned}
& \log (y(t))=\beta_{0}+\frac{\alpha}{1-\alpha-\beta-\delta-\xi} \log \theta(t)^{k}+\frac{\beta}{1-\alpha-\beta-\delta-\xi} \log \theta(t)^{h}+\frac{\delta}{1-\alpha-\beta-\delta-\xi} \log \theta(t)^{b} \\
& +\frac{\xi}{1-\alpha-\beta-\delta-\xi} \log \theta(t)^{e}-\frac{\alpha+\beta+\delta+\xi}{1-\alpha-\beta-\delta-\xi} \log (n+\lambda+\gamma)+\varepsilon(t)
\end{aligned}
$$

The model in equation (22) can be estimated by OLS method. In the new endogenous growth theory it has been argued that the degree of absorption of technological advances increases with increases in the openness of a country. The addition of human, health and education capital along with physical capital improves the performance of the Solow model.

\section{Empirical Study}

For our empirical study we use the annual data of real GDP, Population, real gross fixed capital formation, real physical capital and gross enrollments in primary, secondary and tertiary levels of education taken as a proxy for human capital, health and education expenditure are taken as the proxy of health and education capital for Bangladesh for the year 1990 to 2009. Annual data are collected from the World Economic Indicators and from the key indicators for the Asia and the pacific of Asian Development Bank website. These data are transformed into natural logarithms to account for the expected non-linearities in the relationships and also to achieve stationarity in variance (Chang and Caudill, 2005). The descriptive statistics of these variables are presented in Table-1. From Table-1 we found that the mean return of the $\mathrm{Y}(\mathrm{t}), \mathrm{K}(\mathrm{t}), \mathrm{H}(\mathrm{t}), \mathrm{Q}(\mathrm{t}), \mathrm{B}(\mathrm{t})$ and $\mathrm{E}(\mathrm{t})$ are 7.7436, 6.1983, 4.7897, 4.8394, 2.9619 and 3.7530 respectively. The ranges of the standard deviation of these series are from 0.1580 to 0.6777 . Among these variables $\mathrm{H}(\mathrm{t})$ present the smallest and $\mathrm{K}(\mathrm{t})$ present the highest standard deviation. All of these series are not normally distributed as their kurtosis is less than 3 . This table also present that $\mathrm{Y}(\mathrm{t})$ and $\mathrm{K}(\mathrm{t})$ are positively skewed and rest of series are negatively skewed.

Prior to test for cointegration and implementing the Granger causality test, econometric methodology needs to examine the stationarity for each individual time series. It is important to make sure that these variables are stationary, because if they are not stationary then the standard assumptions for asymptotic analysis in the Granger causality test will not be valid. In our study we applied different popular unit root test such as Augmented Dickey-Fuller (ADF, 1979), Dickey-Fuller (1981), Phillips-Perron (PP, 1988), and Kwiatkowski, Phillips, Schmidt and Shin (KPSS, 1992) test. These tests are done for both trend and without trend. The estimation results for Unit root test statistics for level are given at Table-2. From Table- 2 we found that we cannot reject the null hypothesis of nonstationary which indicates that all of these variables are non stationary both at $1 \%$ and also $5 \%$ significance level for both trend and without trend for their levels. Similar results are obtained for first differences. Then we consider second difference and found that we can reject the null hypothesis which indicate that all of these variables are stationary at $1 \%$ as well as $5 \%$ level of significance except $\mathrm{E}(\mathrm{t})$ series with $\mathrm{ADF}$ test for both trend and without trend but other test confirmed the stationarity(See Table-3). The estimation results for first differences are omitted from here. Having found that all of these variables have unit roots, our next step is to running Johansen (1988) procedure of cointegration. Johansen's procedure of multivariate cointegration requires the existence of sufficient number of time lags. For this purpose we use Akaike Information Criterion with critical values from Osterwald-Lenum (1992) 
which indicate the lag length is 2. Cointegration test based on the Maximum Likelihood method of Johansen (1988) suggests two tests (Maximum Eigen value test and Trace test). The estimated results are given in Table-4.

From table-4 we found that at the Maximum Eigen value test for with and without trend, estimated test statistics is not less than the critical value for $r=0$. This means that the hypothesis of no cointegration is rejected. Similar results are found for the null hypothesis $r \leq 1, r \leq 2$, i.e. the null hypothesis of 1 or 2 cointregration is rejected. To find the number of cointegrating vectors we see that for, $r \leq 3$ the estimated test statistics less than the critical vale which means that there are three cointegrating equations. Similar results are obtained from Trace test. The existence of the cointegrating equations prompts us to confirm the long run equilibrium relation among these variables. The long run parameter estimation results are given at Table-5. From this table we found that in the long run health expenditure has positive and significant effect on the GDP whereas education expenditure has negative effect on the GDP of Bangladesh which is also statistically significant.

Later we present the ECM parameter estimation results. The major advantage of the ECM representation is that it avoids the problem of spurious correlation between dependent and explanatory variables. ECM estimation results are given in Table-6. From this table we found that health and education expenditure are statistically significant and other capital also have significant positive effect on the growth model. It also showed that the error correction term is statistically significant. So an including of health and education expenditure as an investment in health and education capital improve the significance of the coefficient of human and physical capital in the growth model for Bangladesh.

Now we are interested to find out the causal relationship among GDP, health and education expenditure for Bangladesh. For this purpose we use VAR Granger Causality/Block Exogeneity Wald Tests. Under this system, an endogenous variable can be treated as exogenous. The estimated results are given in Table-7. From Table-7 we found that a chi-square (Wald) test statistics of 8.144192 for $\mathrm{B}(\mathrm{t})$ with reference to $\mathrm{Y}(\mathrm{t})$ represent the hypothesis that lagged coefficient of $B(t)$ in the regression equation of $Y(t)$ are equal to zero. Similarly, the lagged coefficient of $E(t)$ as well as block of all coefficients in the regression equation of $\mathrm{Y}(\mathrm{t})$ are equal to zero. Thus health and education expenditure are granger cause for GDP at 0.017 and 0.026 levels of significance respectively. Also all the variables are granger cause for GDP at the 0.0122 level. The test results for $\mathrm{B}(\mathrm{t})$ equation indicate that the lagged coefficients of $Y(t)$ are not equal to zero but the lagged coefficient of $E(t)$ are equal to zero. This indicates that GDP is not granger cause for health expenditure whereas education expenditure is granger cause of health expenditure. Similarly, from the $E(t)$ equation we found that $Y(t)$ and $B(t)$ are granger cause for $E(t)$. This indicates that for education expenditure; GDP and health expenditure are granger cause. So, we found the bidirectional causality among GDP with education expenditure and also education expenditure with health expenditure and only unidirectional causality is obtained from health expenditure to GDP for Bangladesh.

\section{Conclusions}

This paper investigated the causal relationship among health expenditure, education expenditure and GDP for Bangladesh over the period 1990-2009. First we presented the extended form of the Augmented Solow growth model by including education and health expenditure as an investment in health and education capital. From the empirical study we found that health and education expenditure are statistically significant and other capital also have significant positive effect on the growth variable. It also showed that the error correction term is statistically significant. So an including of health and education expenditure as an investment in health and education capital improve the significance of the coefficient of human and physical capital in the growth model for Bangladesh. Secondly we find out the causal relationship among these variables. For this purpose we used Granger Causality/Block Exogeneity Wald Tests. From our empirical study we found the existence of stable and strong long-run relationship among these variables in the growth model. We also found the strong evidence of the unidirectional causality from health expenditure to GDP and bidirectional causality is running from education expenditure to GDP and vice versa and also from education expenditure to health expenditure which indicate that health and education expenditure are helping the GDP of Bangladesh to grow where GDP also influence the education expenditure but it does not influence the health expenditure and also health and education expenditure helping each other to grow up for the case of Bangladesh.

\section{References}

Abramovitz, M. (1986). Catching up, Forging Ahead and Falling Behind. Journal of Economic History, XLVI(2).

Aurangzeb. (2003). Relationship between Health Expenditure and GDP in an Augmented Solow Growth Model for Pakistan: An Application of Co-integration and Error-Correction Modeling, Lahore Journal of Economics, Pakistan, Vol.8, No, 2 
Barro, R. J. (1997). Determinants of Economic Growth: A cross-country empirical study, Cambridge Massachusetts, The MIT Press.

Barro, R. J. and. Lee, J-W. (1993). International Comparisons of Educational Attainment, Journal of Monetary Economics 32, 363-394.

Barro, R. J. and Sala-i-Martin, X. (1995). Economic Growth. New York, McGraw Hill.

Benhabib, J and Spiegel, M. (1994). The Role of Human Capital in Economic Development: Evidence from Aggregate Cross-Country Data. Journal of Monetary Economics, 34(2), pp. 143-173.

Chang, K. and Ying, Y. H. (2006). Economic growth, Human Capital Investment and health expenditure: A study of OECD countries. Hitotsubashi Journal of Economics 47, pp:1-16

Chang, T, and Caudill, S.B. (2005). Financial development and economic growth: the case of Taiwan. Applied Economics, 37, 1329-1335.

Dickey, D.A. and. Fuller, W.A. (1979). Distribution of the Estimators for Autoregressive Time Series with a Unit Root, Journal of the American Statistical Association, 74, p.427-431.

Dickey, D.A and Fuller, W.A. (1981). Likelihood Ratio Statistics for Autoregressive Time Series with a Unit Root, Econometrica, Vol. 49 (1981), pp. 1057-1072.

Easterly, W. and Levine, R. (2001). It's Not Factor Accumulation: Stylized Facts and Growth Models. The World Bank Economic Review, 15(2), pp. 177-219.

Engle, R. F. and Granger, C. W. J. (1987). Co-integration and Error-correction: Representation, Estimation and Testing. Econometrica 55, 251-276.

Gemmell, N. (1996). Evaluating the impacts of human capital stocks and accumulation on economic growth: some new evidence, Oxford Bulletin of Economics and Statistics 58: 9-28

Granger, C.W.J. (1969). Investigating causal relation by econometric and cross sectional method, Econometrica 37 : 424-438.

Grigoriou, C. and Graziosi, G.R. (2005). Why do education expenditure fail to decrease child labor? Impact and optimal composition of social expenditures, online Publication, http://www.cerdi.org/uploads/sfCmsContent/html/199/Rota_Grigoriou.pdf

Hall, R. E. and Jones, C. I. (1999). Why Do Some Countries Produce So Much More Output Than Others? Quarterly Journal of Economics, pp. 83-116.

Hendry, D. F. (1979). Productive Failure Econometric Modelling in Macroeconomics: The Transmission Demand for Money, in Economic Modeling: Current Issues and Problems in Macroeconomic Modeling in the UK and the USA, (ed.), London: P. Ormerod.

Hendry, D.F (1995). Dynamic Econometrics, London: Oxford University Press, pp. 577-629

Himissa, M.T., Habibullah, M.S., and Baharom, A.H.(2009). The relationship between defense, education and health expenditure in selected Asian countries. International Journal of Economics and Finance, Vol. 1, No.2

Johansen, S. (1988). Statistical Analysis of Co-integration Vectors, Journal of Economic Dynamics and Control, Vol. 12, pp. 231-254.

Klenow, P. J. and Rodriguez-Clare, A. (1997). The Neoclassical Revival in Growth Economics: Has It Gone Too Far? Econpapers, 12, pp. 73-114.

Kwiatkowski, D., P. Phillips, P. Schmidt and Shin, Y. ( 1992). Testing the Null Hypothesis of Stationarity against the Alternative of a Unit Root, Journal of Econometrics, Vol. 54, pp. 159-178.

McKinnon, R. (1991). The Order of Economic Liberalization: Financial Control in the Transition to a Market Economy. Baltimore, MD: John Hopkins University Press.

Mankiw, N.G., Romer, D.and Weil, D.N. (1992). A Contribution to the Empirics of Economic Growth, Quarterly Journal of Economics 107, 407-437

Miller, S.M. and Upadhyay M.P. (2000). The Effects of Openness, Trade Orientation and Human Capital on Total Factor Productivity, Journal of Development Economics 63, 399-423.

Nancy, D. and H. Paul (2001). Health Care Spending and Economic Output: Granger Causality, Applied Economic Letters 8(8), 561-64. 
Nelson, R. R. and Phelps, E. S. (1966). Investment in Humans, Technological Diffusion and Economic Growth. American Economic Review, 56(1/2), pp. 69-75.

Osterwald-Lenum, M., (1992). Practioners corner a note with quartiles of the asymptotic distribution of the maximum likelihood cointegration rank test statistics. Oxford Bulletin of Economics and Statistics, 54, 461-472.

Phillips, P. C. B. and Perron, P. (1988). Testing for a Unit Root in Time Series Regression, Biometrika, Vol. 32, pp. 301-318

Patterson, K. (2002). An Introduction to Applied Econometrics: A Time Series Approach. New York: Palgrave

Siddiqui, R., U. Afridi, and Haq R. (1995). Determinants of Expenditure on Health in Pakistan, The Pakistan Development Review 34(4), 959-970.

Solow R.M. (1956). A Contribution to the Theory of Economic Growth, Quarterly Journal of Economics 70, 427-443

Romer, P (1990a). Endogenous Technical Change. Journal of Monetary Economics, 96, pp. S71-S102.

Romer, P. (1990b). Human Capital and Growth: Theory and Evidence. Carnegie-Rochester Conference Series on Public Policy, 32, pp. 251-286.

Table-1. Descriptive statistics of these variables

\begin{tabular}{|l|l|l|l|l|l|l|l|l|}
\hline Series & Mean & Median & Max. & Min. & $\begin{array}{l}\text { Standard } \\
\text { Deviatio } \\
n\end{array}$ & Skewness & Kurtosis & $\begin{array}{l}\text { Jarque-Bera } \\
(J B) \text { test } \\
(p-v a l u e)\end{array}$ \\
\hline $\mathrm{Y}(\mathrm{t})$ & 7.7436 & 7.7327 & 8.723 & 6.911 & 0.5483 & 0.1875 & 1.9334 & $\begin{array}{l}1.065 \\
(0.587)\end{array}$ \\
\hline $\mathrm{K}(\mathrm{t})$ & 6.1983 & 6.2459 & 7.312 & 5.142 & 0.6777 & 0.0041 & 1.8157 & $\begin{array}{l}1.168 \\
(0.557)\end{array}$ \\
\hline $\mathrm{H}(\mathrm{t})$ & 4.7897 & 4.8520 & 5.003 & 4.584 & 0.1580 & -0.0921 & 1.3007 & $\begin{array}{l}2.435 \\
(0.295)\end{array}$ \\
\hline $\mathrm{Q}(\mathrm{t})$ & 4.8394 & 4.8454 & 4.9711 & 4.691 & 0.0872 & -0.1531 & 1.8122 & $\begin{array}{l}1.253 \\
(0.534)\end{array}$ \\
\hline $\mathrm{B}(\mathrm{t})$ & 2.9619 & 3.0880 & 3.761 & 1.824 & 0.5729 & -0.4446 & 2.3130 & $\begin{array}{l}1.0522 \\
(0.590)\end{array}$ \\
\hline $\mathrm{E}(\mathrm{t})$ & 3.7530 & 3.8397 & 4.663 & 2.541 & 0.6699 & -0.4629 & 2.1341 & $\begin{array}{l}1.341 \\
(0.511)\end{array}$ \\
\hline
\end{tabular}

Table-2. Unit roots test for level with trend and without trend

\begin{tabular}{|l|l|l|l|l|l|l|l|l|}
\hline & \multicolumn{2}{l}{} & \multicolumn{2}{l|}{ DF } & \multicolumn{2}{l|}{ PP } & \multicolumn{2}{l|}{ KPSS } \\
\hline Variables & Without Trend & With Trend & Without Trend & With Trend & Without Trend & With Trend & Without Trend & With Trend \\
\hline \multirow{2}{*}{ Y(t) } & 3.338 & -0.714 & -0.053 & -1.935 & 2.899 & 0.539 & 0.741 & 0.327 \\
& $(-3.831)$ & $(-4.667)$ & $(-2.717)$ & $(-3.770)$ & $(-3.831)$ & $(-4.532)$ & $(0.739)$ & $(0.216)$ \\
\hline \multirow{2}{*}{ K(t) } & 0.980 & -2.878 & -0.308 & -3.116 & 0.791 & -2.061 & 0.615 & 0.328 \\
& $(-3.831)$ & $(-4.571)$ & $(-2.699)$ & $(-3.770)$ & $(-3.831)$ & $(-4.532)$ & $(0.739)$ & $(0.216)$ \\
\hline \multirow{2}{*}{$\mathrm{H}(\mathrm{t})$} & -0.187 & -2.829 & -0.149 & -2.642 & -0.187 & -2.852 & 0.566 & 0.247 \\
& $(-3.831)$ & $(-4.532)$ & $(-2.692)$ & $(-3.770)$ & $(-3.831)$ & $(-4.532)$ & $(0.739)$ & $(0.216)$ \\
\hline \multirow{2}{*}{$\mathrm{Q}(\mathrm{t})$} & -3.261 & -4.498 & 0.605 & -2.737 & -1.891 & -0.620 & 0.613 & 0.264 \\
& $(-3.959)$ & $(-4.728)$ & $(-2.728)$ & $(-3.770)$ & $(-3.831)$ & $(-4.532)$ & $(0.739)$ & $(0.216)$ \\
\hline \multirow{2}{*}{$\mathrm{B}(\mathrm{t})$} & -1.906 & -2.681 & -0.596 & -2.600 & -2.620 & -3.168 & 0.611 & 0.382 \\
& $(-3.857)$ & $(-4.532)$ & $(-2.692)$ & $(-3.770)$ & $(-3.831)$ & $(-4.532)$ & $(0.739)$ & $(0.216)$ \\
\hline \multirow{2}{*}{$\mathrm{E}(\mathrm{t})$} & -1.216 & -2.896 & -1.354 & -2.791 & -1.216 & -1.321 & 0.597 & 0.148 \\
& $(-3.831)$ & $(-4.571)$ & $(-2.669)$ & $(-3.770)$ & $(-3.831)$ & $(-4.532)$ & $(0.739)$ & $(0.216)$ \\
\hline
\end{tabular}

Note: ( ) contains the critical value 
Table-3. Unit roots test for second difference with and without trend

\begin{tabular}{|l|l|l|l|l|l|l|l|l|}
\hline & \multicolumn{2}{|l}{ ADF } & \multicolumn{2}{l|}{ DF } & \multicolumn{2}{l|}{ KP } \\
\hline Variables & Without Trend & With Trend & Without Trend & With Trend & Without Trend & With Trend & Without Trend & With Trend \\
\hline \multirow{2}{*}{ Y(t) } & -3.986 & -6.044 & -3.680 & -3.987 & -5.966 & -5.313 & 0.500 & 0.122 \\
& $(-3.886)$ & $(-4.667)$ & $(-2.708)$ & $(-3.770)$ & $(-3.886)$ & $(-4.616)$ & $(0.739)$ & $(0.216)$ \\
\hline \multirow{2}{*}{ K(t) } & -4.308 & -4.765 & -4.411 & -4.423 & -5.579 & -5.255 & 0.307 & 0.066 \\
& $(-3.887)$ & $(-4.616)$ & $(-2.708)$ & $(-3.770)$ & $(-3.886)$ & $(-4.616)$ & $(0.739)$ & $(0.216)$ \\
\hline \multirow{2}{*}{$\mathrm{H}(\mathrm{t})$} & -7.364 & -7.157 & -6.772 & -7.588 & -15.146 & -18.879 & 0.216 & 0.095 \\
& $(-3.886)$ & $(-4.616)$ & $(-2.708)$ & $(-3.770)$ & $(-3.886)$ & $(-4.616)$ & $(0.739)$ & $(0.216)$ \\
\hline \multirow{2}{*}{$\mathrm{Q}(\mathrm{t})$} & -7.498 & -12.975 & -8.402 & -10.738 & -8.981 & -8.572 & 0.272 & 0.164 \\
& $(-4.004)$ & $(-4.800)$ & $(-2.740)$ & $(-3.770)$ & $(-3.886)$ & $(-4.616)$ & $(0.739)$ & $(0.216)$ \\
\hline \multirow{2}{*}{$\mathrm{B}(\mathrm{t})$} & -5.504 & -5.348 & -5.725 & -5.661 & -20.198 & -19.561 & 0.390 & 0.133 \\
& $(-3.920)$ & $(-4.667)$ & $(-2.717)$ & $(-3.770)$ & $(-3.886)$ & $(-4.616)$ & $(0.739)$ & $(0.216)$ \\
\hline \multirow{2}{*}{$\mathrm{E}(\mathrm{t})$} & -3.573 & -3.349 & -1.888 & -5.218 & -8.445 & -6.658 & 0.135 & 0.074 \\
& $(-3.886)$ & $(-4.616)$ & $(-2.717)$ & $(-3.770)$ & $(-3.886)$ & $(-4.616)$ & $(0.216)$ & $(0.216)$ \\
\hline
\end{tabular}

Table-4. Johansen test for co-integration among these variables

\begin{tabular}{|c|c|c|c|c|c|c|}
\hline \multicolumn{7}{|c|}{ Maximum eigen value test } \\
\hline \multirow{2}{*}{ Null Hypothesis } & \multirow{2}{*}{ Alternative Hypothesis } & \multicolumn{2}{|c|}{ Without trend } & \multicolumn{2}{|l|}{ With trend } & \multirow[t]{2}{*}{ Conclusion } \\
\hline & & Test Statistics & Critical value & Test Statistics & Critical value & \\
\hline$r=0$ & $r=1$ & 86.26758 & 33.87687 & 107.7601 & 37.16359 & \multirow{4}{*}{ Three co-integration equation } \\
\hline$r \leq 1$ & $r=2$ & 45.20355 & 27.58434 & 54.51307 & 30.81507 & \\
\hline$r \leq 2$ & $r=3$ & 30.72118 & 21.13162 & 38.40962 & 24.25202 & \\
\hline$r \leq 3$ & $r=4$ & 8.878343 & 14.26460 & 12.93299 & 17.14769 & \\
\hline \multicolumn{7}{|c|}{ Trace test } \\
\hline$r=0$ & $r=1$ & 174.5405 & 69.81889 & 223.7260 & 79.34145 & \multirow{4}{*}{ Three co-integration equation } \\
\hline$r \leq 1$ & $r=2$ & 88.27295 & 47.85613 & 115.9660 & 55.24578 & \\
\hline$r \leq 2$ & $r=3$ & 43.06940 & 29.79707 & 61.45290 & 35.01090 & \\
\hline$r \leq 3$ & $r=4$ & 12.34822 & 15.49471 & 16.04328 & 18.39771 & \\
\hline
\end{tabular}

Table-5. Long run parameter estimation results

\begin{tabular}{|c|c|c|c|}
\hline $\begin{array}{c}\text { Explanatory } \\
\text { Variable }\end{array}$ & Coefficient & Standard error & t-statistic \\
\hline $\mathrm{Y}(\mathrm{t})$ & -1 & - & - \\
\hline $\mathrm{K}(\mathrm{t})$ & -0.8123 & 0.0507 & -9.892881 \\
\hline $\mathrm{H}(\mathrm{t})$ & 1.423 & 0.2537 & 2.363999 \\
\hline $\mathrm{P}(\mathrm{t})$ & 2.349 & 0.3823 & 2.775866 \\
\hline $\mathrm{B}(\mathrm{t})$ & -0.7918 & 0.0232 & -2.610845 \\
\hline $\mathrm{E}(\mathrm{t})$ & 0.4356 & 0.0193 & 2.399811 \\
\hline \multicolumn{4}{|c|}{ Log Likelihood=289.014 } \\
\hline
\end{tabular}

Note: (Normalized on the basis on the GDP) 
Table-6. ECM parameter estimation results

\begin{tabular}{|c|c|c|c|}
\hline Variables & $\mathrm{Y}(\mathrm{t})$ & $\mathrm{B}(\mathrm{t})$ & $\mathrm{E}(\mathrm{t})$ \\
\hline Constant & $-0.61(-3.41)$ & $0.063(1.478)$ & $0.048(1.112)$ \\
\hline EC term & $-0.87(-3.11)$ & $-0.333(-2.102)$ & $-0.647(-1.201)$ \\
\hline$\Delta \mathrm{Y}(\mathrm{t})$ & $1.045(4.12)$ & $1.598(0.155)$ & $0.879(0.124)$ \\
\hline$\Delta \mathrm{Y}(\mathrm{t}-1)$ & $0.987(3.142)$ & $-2.812(-1.245)$ & $-1.245(-2.110)$ \\
\hline$\Delta \mathrm{Y}(\mathrm{t}-2)$ & $-2.478(-0 . .243)$ & $0.272(2.142)$ & $1.785(2.115)$ \\
\hline$\Delta \mathrm{K}(\mathrm{t})$ & $-0.121(-1.471)$ & $0.987(2.596)$ & $0.736(1.642)$ \\
\hline$\Delta \mathrm{K}(\mathrm{t}-1)$ & $0.591(2.781)$ & $-1.658(-2.880)$ & $-0.954(-2.42)$ \\
\hline$\Delta \mathrm{K}(\mathrm{t}-2)$ & $-1.107(-3.211)$ & $0.786(2.125)$ & $1.112(2.356)$ \\
\hline$\Delta \mathrm{H}(\mathrm{t})$ & $0.427(0.147)$ & $0.594(3.651)$ & $0.548(2.778)$ \\
\hline$\Delta \mathrm{H}(\mathrm{t}-1)$ & $0.751(8.171)$ & $-1.145(-2.014)$ & $-0.788(-2.113)$ \\
\hline$\Delta \mathrm{H}(\mathrm{t}-2)$ & $-1.809(-3.151)$ & $0.264(1.254)$ & $1.684(2.758)$ \\
\hline$\Delta \mathrm{Q}(\mathrm{t})$ & $0.736(2.541)$ & $0.664(1.110)$ & $1.245(3.120)$ \\
\hline$\Delta \mathrm{Q}(\mathrm{t}-1)$ & $-2.678(-6.812)$ & $-2.145(-2.220)$ & $0.548(0.154)$ \\
\hline$\Delta \mathrm{Q}(\mathrm{t}-2)$ & $0.267(4.111)$ & $0.988(4.124)$ & $-1.112(-2.365)$ \\
\hline$\Delta \mathrm{B}(\mathrm{t})$ & $1.912(3.218)$ & $2.314(0.112)$ & $0.282(1.246)$ \\
\hline$\Delta \mathrm{B}(\mathrm{t}-1)$ & $0.987(3.114)$ & $-0.987(-2.113)$ & $-1.350(-2.987)$ \\
\hline$\Delta \mathrm{B}(\mathrm{t}-2)$ & $-0.521(-3.124)$ & $1.225(4.110)$ & $0.899(2.782)$ \\
\hline$\Delta E(t)$ & $1.184(3.140)$ & $2.113(0.128)$ & $0.354(1.389)$ \\
\hline$\Delta \mathrm{E}(\mathrm{t}-1)$ & $-0.047(-5.133)$ & $3.214(2.115)$ & $-2.448(-5.243)$ \\
\hline$\Delta \mathrm{E}(\mathrm{t}-2)$ & $0.883(2.478)$ & $-2.112(-3.159)$ & $0.548(2.154)$ \\
\hline Adj. $R^{2}$ & 0.654 & 0.478 & 0.887 \\
\hline D-W Statistic & 1.245 & 1.987 & 2.012 \\
\hline
\end{tabular}


Table-7. VAR Granger Causality tests output

\begin{tabular}{|c|c|c|c|c|}
\hline Dependent Variable & Excluded & $\chi^{2}$ statistics & DF & $P$ value \\
\hline \multirow[t]{6}{*}{$Y(t)$} & $\mathbf{K}(\mathbf{t})$ & 10.00433 & 2 & 0.0067 \\
\hline & $\mathrm{H}(\mathrm{t})$ & 2.262952 & 2 & 0.3226 \\
\hline & $Q(t)$ & 7.451497 & 2 & 0.0241 \\
\hline & $B(t)$ & 8.144192 & 2 & 0.0170 \\
\hline & $\mathbf{E}(\mathbf{t})$ & 7.289901 & 2 & 0.0261 \\
\hline & All Values & 22.63838 & 10 & 0.0122 \\
\hline \multirow[t]{6}{*}{$\mathrm{K}(\mathrm{t})$} & $Y(t)$ & 26.54091 & 2 & 0.0000 \\
\hline & $\mathbf{H}(\mathbf{t})$ & 10.22024 & 2 & 0.0060 \\
\hline & $Q(t)$ & 31.32999 & 2 & 0.0000 \\
\hline & $\mathbf{B}(\mathbf{t})$ & 22.05771 & 2 & 0.0000 \\
\hline & $E(t)$ & 10.75455 & 2 & 0.0046 \\
\hline & All Values & 77.46304 & 10 & 0.0000 \\
\hline \multirow[t]{6}{*}{$\mathrm{H}(\mathrm{t})$} & $\mathbf{Y}(\mathbf{t})$ & 6.600800 & 2 & 0.0369 \\
\hline & $\mathbf{K}(\mathbf{t})$ & 7.012898 & 2 & 0.0300 \\
\hline & $\mathrm{Q}(\mathrm{t})$ & 1.126706 & 2 & 0.5693 \\
\hline & $\mathrm{B}(\mathrm{t})$ & 0.877359 & 2 & 0.6449 \\
\hline & $E(t)$ & 0.546562 & 2 & 0.7609 \\
\hline & All Values & 17.66763 & 10 & 0.0608 \\
\hline \multirow[t]{6}{*}{$\mathrm{Q}(\mathrm{t})$} & $\mathbf{Y}(\mathbf{t})$ & 17.77177 & 2 & 0.0001 \\
\hline & $\mathbf{K}(\mathbf{t})$ & 9.358301 & 2 & 0.0093 \\
\hline & $\mathrm{H}(\mathrm{t})$ & 0.167755 & 2 & 0.9195 \\
\hline & $B(t)$ & 17.43029 & 2 & 0.0002 \\
\hline & $E(t)$ & 7.287511 & 2 & 0.0262 \\
\hline & All Values & 35.06639 & 10 & 0.0001 \\
\hline \multirow[t]{6}{*}{$\mathrm{B}(\mathrm{t})$} & $\mathrm{Y}(\mathrm{t})$ & 0.918081 & 2 & 0.6319 \\
\hline & $\mathrm{K}(\mathrm{t})$ & 3.242648 & 2 & 0.1976 \\
\hline & $\mathrm{H}(\mathrm{t})$ & 2.632448 & 2 & 0.2681 \\
\hline & $\mathrm{Q}(\mathrm{t})$ & 3.985817 & 2 & 0.1363 \\
\hline & $E(t)$ & 7.360387 & 2 & 0.0252 \\
\hline & All Values & 23.89416 & 10 & 0.0079 \\
\hline \multirow[t]{6}{*}{$E(t)$} & $Y(t)$ & 8.339967 & 2 & 0.0142 \\
\hline & $K(t)$ & 4.945540 & 2 & 0.0844 \\
\hline & $\mathrm{H}(\mathrm{t})$ & 0.281264 & 2 & 0.8688 \\
\hline & $Q(t)$ & 4.945540 & 2 & 0.0844 \\
\hline & $B(t)$ & 7.597670 & 2 & 0.0224 \\
\hline & All Values & 28.92100 & 10 & 0.0013 \\
\hline
\end{tabular}

Note: Bold mark indicates significant 